\title{
Mollusc fauna along an offshore-fjord gradient
}

\author{
L. Buhl-Mortensen*, T. Høisæter \\ Department of Fisheries and Marine Biology, University of Bergen, Høyteknologisenteret, N-5020 Bergen, Norway
}

\begin{abstract}
To explore the relationship between molluscan species diversity and selected environmental variables along a fjord gradient, we took 2 replicate samples with an epibenthic sledge at 10 localities along a transect from the Norwegian Trough to the inner parts of a fjord system. The Shannon-Wiener diversity $\left(H^{\prime}\right)$ of 65 species decreased markedly from offshore to the innermost stations; there were fewer but more abundant species in the fjords than offshore. Diversity was positively correlated to sill depth, and negatively correlated to distance to 'species pool' (= recruitment area), C/N, and \% carbon in the surface sediment. TWINSPAN, a numerical classification method, divided the mollusc fauna into 3 groups: (I) offshore, (II) outer fjord, and (III) inner fjord fauna. The relation between the faunal pattern and 15 environmental variables was analysed with Canonical Correspondence Analysis (CCA). The environmental variables that explained most of the variance between species in the CCA were sill depth, distance to 'species pool', C/N, \% C, \% loss on ignition, and median phi-size $(\phi)$, and together these variables accounted for $74 \%$ of the variance in the species data. Four hypothetical explanations are offered as to why the diversity of the deep fjord fauna of molluscs and amphipods is low compared to adjacent offshore areas. The 2 most likely explanations are that the sediment habitat (i.e. food resources, measured as $\mathrm{C} / \mathrm{N}$, and grain size) may be more diverse offshore than in fjords, and that the higher influx of organic matter in fjords, measured as \% carbon in the sediment, may favour the dominance of a few opportunistic species.
\end{abstract}

\section{INTRODUCTION}

The benthic fauna of Norwegian fjords has been little studied, and in general few attempts have been made to compare the fjord fauna with the fauna of adjacent offshore areas (for a review see Pearson 1980). Fjords are, by definition, enclosed marine basins with a restricted and shallow connection to the open sea. The main factors influencing the benthic fauna of fjords are proximity to land, which affects the input of organic and inorganic material to the sediment, restricted water exchange, which sometimes affects oxygen conditions in the more isolated basins, and the exchange of planktonic larvae with adjacent areas. These factors could have a negative effect on the diversity of the benthic fauna. High input of organic matter and low oxygen levels are associated with low species richness (e.g. Pearson \& Rosenberg 1978, Weston 1990), and restricted larval exchange may result in isolated fjord populations and low colonization rates.

- Formerly L. Buhl-Jensen
In one of the few published studies relating benthic fjord fauna to the fauna in adjacent, comparable environments, Mclntyre (1964) compared the meiobenthos of Fladen Ground in the North Sea with an area of similar depth and sediment in Loch Nevis on the Scottish west coast. He found that species diversity of benthic copepods was highest in the fjord. On the other hand, in a parallel investigation of the benthic macrofauna in the same 2 localities (McIntyre 1961), he found higher diversity on Fladen than in Loch Nevis. Holthe (1978) found that the diversity of terebellomorph polychaetes in Norwegian waters was generally highest on the coast, lower in the adjacent fjords, and still lower on the shelf. Buhl-Jensen (1986) and Buhl-Jensen \& Fosså (1991) found that species richness of benthic amphipods on the continental shelf was generally higher than at comparable depths in adjacent fjords, both on the Norwegian and the Swedish west coast.s. However, the distribution of the more mobile crustaceans, the decapods and mysids, showed no clear difference in diversity (Buhl-Jensen \& Fosså 1991). Josefson (1985) found a low diversity of soft sediment infauna in the Skagerrak basin compared with the adjacent shelf on 
the Swedish west coast. He suggested, as one of several explanations, that the sill between the Skagerrak basin and the Norwegian Trough to the northwest could act as a 'geographical barrier' and that the Skagerrak basin may be viewed as a biogeographical 'island' partly isolated from the main species pool.

Two possible explanations as to why the diversity of the amphipod fauna is lower inside than outside
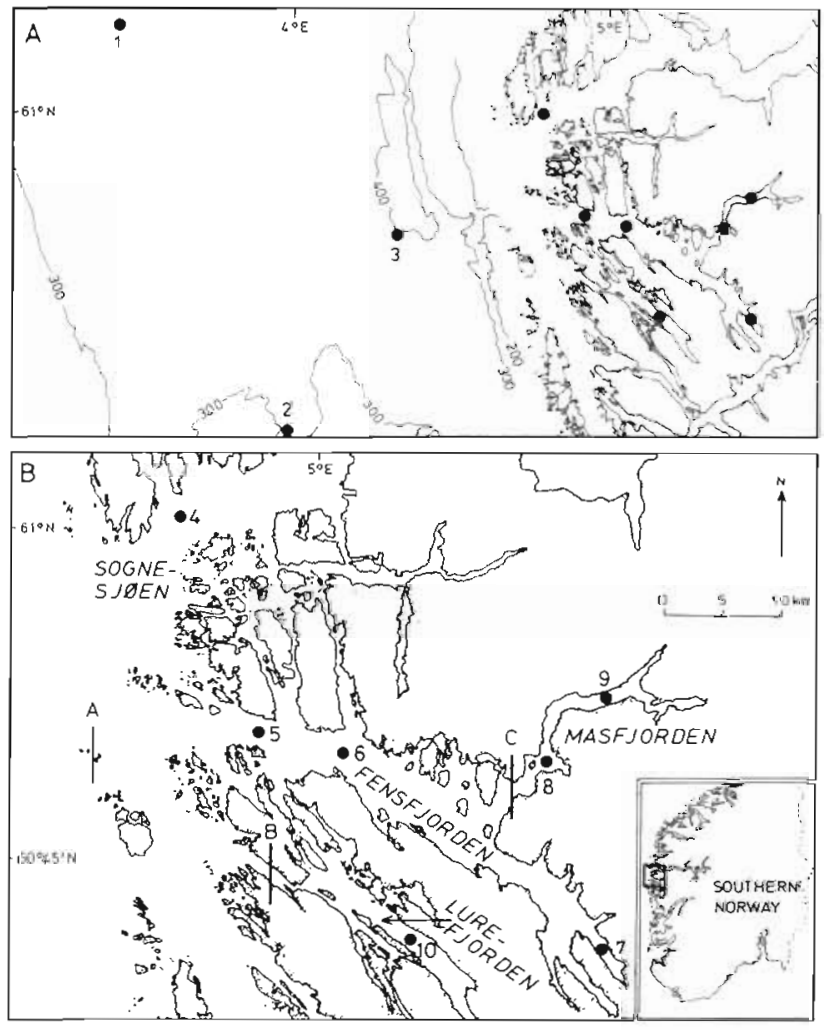

C

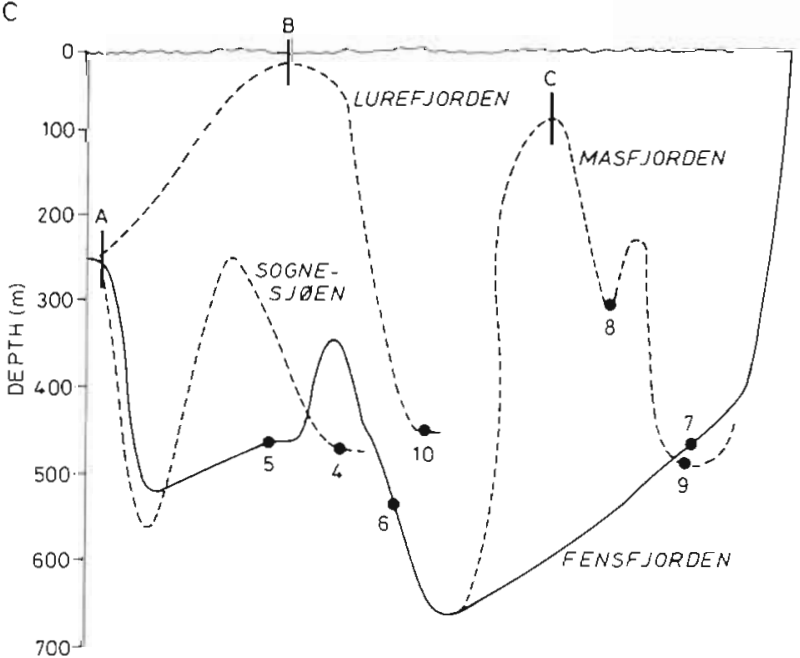

Fig. 1. Sampling area from the Norwegias Trough to the inner parts of an adjacent fjord system showing (A) shelf and (B) fjord stations. (C) Depth profile of the fjords with position of stations fjords (Buhl-Jensen 1986) are: (1) Because amphipods are brooders and thus have no pelagic dispersal stage, the sill of fjords may act as a colonization barrier; and (2) The soft muddy bottoms of fjord basins may offer a less diverse environment, i.e. grain-size and food composition, for the benthic fauna than offshore bottoms at similar depths.

To distinguish between these hypotheses, the belowsill distributional pattern of a group of nonbrooding macrofauna of limited mobility should be compared with that of the amphipods. A fjord sill would presumably act as less of a barrier to organisms with pelagic larvae, and thus if Explanation 1 is valid, these organisms should be more equally represented in both habitats than the amphipods. On the other hand, one should expect more or less the same diversity pattern for benthic organisms with different dispersal abilities if Explanation 2 should prove to be the more important one.

We chose benthic molluscs as a suitable taxonomic group for this comparison. Molluscs are presumably at least as dependent on the sediment environment as benthic amphipods, and the diversity pattern of molluscs in relation to environmental factors may indicate whether the low diversity observed for amphipods is a general feature of benthic fjord faunas, and if so, whether it can be related to properties specific to fjords.

Most marine molluscs have a pelagic larval stage (Ockelmann 1965, Mileikovsky 1971). The distribution pattern of mollusc species compared with the length of pelagic larval stage may show whether dispersal by larvae is important for the successful colonization of fjords by benthic organisms living below sill depth.

Therefore our objectives for the present investigation were to: (1) investigate the diversity pattern of molluscs inhabiting the deep-water (300 to $500 \mathrm{~m}$ ) soft bottoms along a transect from offshore to the inner fjord environment; (2) relate any faunal pattern observed to environmental factors; (3) compare the distribution of species with their type of larval development. For the purpose of this investigation, we define a 'species pool' as the faunal assemblage outside the fjords, from which the hypothetical fjord colonizers might be recruited.

\section{MATERIAL AND METHODS}

Study area. The 10 investigated localities are situated on a transect from the Norwegian Trough to the inner parts of an adjacent fjord system (Fig. 1A). Stns 1 to 3 (called the offshore stations below) are located in the Norwegian Trough. This area was chosen to represent the 'species pool', i.e. recruitment area, for the adjacent fjord fauna. Since the shelf outside the southwestern part of the Norwegian coast is poorly defined 
and rather narrow, our 'species pool' is placed in the northern part of the Norwegian Trough. The Atlantic water flows northeast along the upper slope to the west and north of Shetland, partly turning south and into the Norwegian Trough at the Tampen Plateau northeast of Shetland (Furnes et al. 1986). This current, flowing south along the western slope of the Norwegian Trough, has frequent deflections across the Trough towards the Norwegian coast, and virtually all of the Atlantic water is diverted across the Trough and into a northward flow along the coast between 61 and $59^{\circ} \mathrm{N}$ (Furnes et al. 1986). The other 7 localities are inside fjords and represent a gradient of topographic isolation (Fig. 1B). Stn 5 is the most accessible, lying behind only one relatively deep (250 m) sill. Stns 4, 6 \& 7 lie behind two deep sills, Stn 8 behind three and Stn 9 behind four sills. Stn 10 is presumably the most isolated locality, lying behind a very shallow sill $(20 \mathrm{~m})$. The hydrography of the fjords has only been studied a few times for short periods. What is known about the bottom water exchange can be summarized as follows: Stns 4 to 7 experience annual bottom water exchanges every autumn/winter (J. Aure pers. comm.); at Stns 8 \& 9 bottom water exchange seems to occur at 2 to $4 \mathrm{yr}$ intervals (Aksnes et al. 1989); and at Stn 10 the hydrography has only been investigated for $1 \mathrm{yr}$, and no bottom water exchange was observed (Golmen 1991). One would expect even less frequent exchanges at Stn 10 than at Stns $8 \& 9$. All localities are situated on level, muddy bottoms with oxygen values in the water well above $2 \mathrm{ml} \mathrm{l}^{-1}$. Lack of oxygen is thus never a problem.

Sampling. Molluscs were collected in October and November 1988 from all stations except Stn 2. Molluscs from Stn 2 and all sediment samples were collected in March 1989.

Animals were sampled with an epibenthic sledge, with 2 replicates at each station. The sledge had an opening of $80 \times 20 \mathrm{~cm}$ and was $2 \mathrm{~m}$ long. It sampled roughly the upper $5 \mathrm{~cm}$ of the sediment depending on sediment quality (J. A. Sneli pers. comm.). The sides were made of metal plates with holes $1 \mathrm{~mm}$ in diameter. The mean speed during the $10 \mathrm{~min}$ long hauls was 1 knot, which gives a maximum sampled area of ca $250 \mathrm{~m}^{2}$. Samples were sieved through a $1.0 \mathrm{~mm}$ screen, preserved in $4 \%$ neutralized formalin and later transferred to $96 \%$ alcohol before identification. All benthic molluscs were determined to species except for caudofoveates and solenogasters and a few scattered juveniles impossible to identify exactly. Nomenclature follows Høisæter (1986) except for a few recent emendations in the Eulimidae (Bouchet \& Warén 1986), the Nuculanidae (Warén 1989b), and the Scaphopoda (Jones \& Baxter 1987).

Two box cores $\left(0.1 \mathrm{~m}^{2}\right.$; Jonasson \& Olausson 1966) were taken at each station for sediment samples. The distance between the 2 cores was approximately equal to the length of a sledge haul, ca $300 \mathrm{~m}$. Two subsamples were taken from each box core with a plastic corer, $25 \mathrm{~cm}$ long and $6 \mathrm{~cm}$ in diameter, and frozen for later analysis. The uppermost $2 \mathrm{~cm}$ of frozen sediment was later cut off and pooled for each box-core sample before analysis.

Sediment analyses. The grain-size fraction $<0.063$ $\mathrm{mm}$ was determined using the pipette method (Buchanan 1984), and the fraction $>0.063 \mathrm{~mm}$ was dry sieved.

Loss on ignition was obtained as the difference in weight between the dried sample $\left(12 \mathrm{~h}\right.$ at $\left.105^{\circ} \mathrm{C}\right)$ and the sample after ignition in a muffle furnace for $1 \mathrm{~h}$ at $550^{\circ} \mathrm{C}$.

The weight percentage of organic carbon (C) and total nitrogen $(\mathrm{N})$ was determined with a Carlo Erba model 1106 CHN analyzer. To obtain carbonate-free sediment, samples were treated with $0.25 \mathrm{M} \mathrm{HCl}$ until no visible reaction occurred and dried at $50^{\circ} \mathrm{C}$ overnight.

Numerical methods. Diversity: The number of species at the stations were compared using Rarefaction Analysis (RA) (Hurlbert 1971, Simberloff 1978). RA is a statistical method for estimating the expected number of species, E[S], in a random sample of individuals taken from a collection. This method makes it possible to compare species richness for a standardized sample size and is recommended when samples differ in number of individuals (James \& Rathbun 1981, Magurran 1988, Soetaert \& Heip 1990). E[S] was calculated for samples rarefied to the size of 200 individuals. For samples with fewer individuals, the observed number of species was used.

Species diversity $\left(H^{\prime}\right)$ was calculated for each sample using the formula

$H^{\prime}=-\sum_{i=1}^{S}\left(N_{i} / N\right) \log _{2}\left(N_{i} / N\right) \quad$ (Shannon \& Weaver 1949)

where $S=$ total no. of species; $N=$ total no. of individuals; and $N_{i}=$ no. of individuals of the ith species.

Faunal patterns: Samples and species were classified using Two-Way Indicator Species Analysis (TWINSPAN) (Hill 1979). TWINSPAN is a dichotomous divisive classification method based on the partitioning of the first axis of Correspondence Analysis. Seven so-called 'pseudospecies cut levels' were used to transform the abundance data, and we grouped the abundance data as follows: 1-4, 5-9, 10-49, 50-99, 100-499, 500-999 and $>1000$ individuals. An account of the method is given by van Tongeren (1987). Only species that occurred in 3 or more samples were included in the analysis.

To investigate the relation between faunal patterns and environmental variables, Canonical Correspon- 


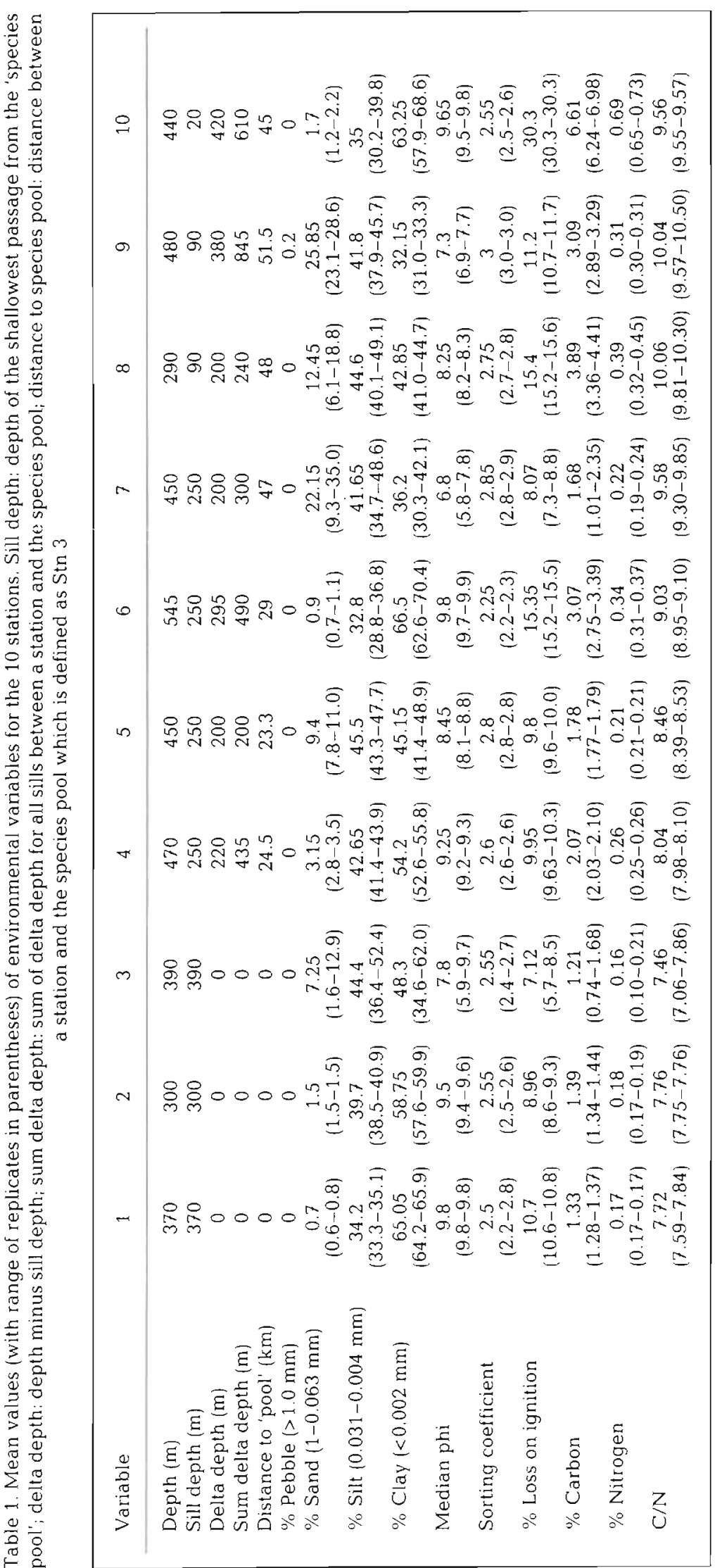

dence Analysis (CCA) and Detrended Correspondence Analysis (DCA) were performed using the program CANOCO (version 3.1) (ter Braak 1990). CCA is a constrained ordination technique that can be used to provide a simultaneous ordination of species, sites and environmental variables. With this technique, ordination axes are constrained to be linear combinations of the environmental variables used in the analysis. The underlying theory of this method is presented in ter Braak (1987). Only species occurring in 3 or more samples were included in the analysis. The data were square root transformed to prevent abundant species from swamping the results.

Within the CCA procedure, forward selection of the environmental variables and Monte Carlo permutation tests were used to test the significance of each environmental variable. The variables were further evaluated by examining intra-set correlations (correlations between species axes and environmental variables). DCA, an unconstrained ordination technique, was used to check whether the environmental variables were sufficient to account for the major patterns in the species variance. Detrending by segments (26 segments) was used.

\section{RESULTS}

\section{The environment}

The grain-size distribution of the sediment differed little among stations (Table 1). Stns $3,5,7,8 \& 9$ have all fairly low median phi-values due to a high proportion of fine sand in the sediment, but there is no clear gradient in grain-size distribution of sediments from offshore to inner fjord stations. The amount and quality of organic matter in the upper $2 \mathrm{~cm}$ of sediment, however, showed a clear gradient from offshore to inner fjord localities. Percentage loss on ignition, $\% \mathrm{C}, \% \mathrm{~N}$, and the $\mathrm{C} / \mathrm{N}$ ratios increased along this gradient. Percentage loss on ignition, $\% \mathrm{C}$, and $\% \mathrm{~N}$ were particularly high at the landlocked Stn 10, the most geographically isolated locality sampled. The range of $\mathrm{C} / \mathrm{N}$ values was distinctly 


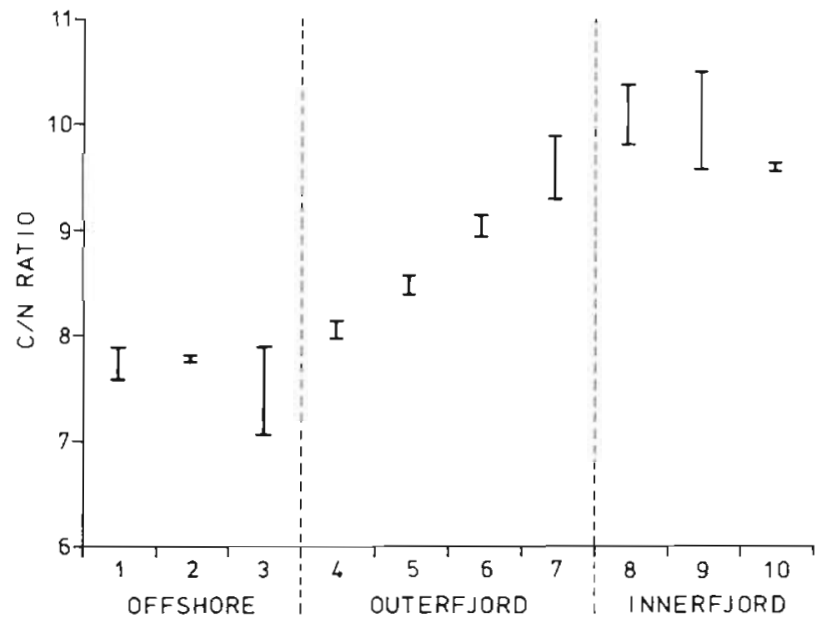

Fig. 2. $\mathrm{C} / \mathrm{N}$ ratio in the surface sediment (upper $2 \mathrm{~cm}$ ) along the shelf-fjord gradient. Range of the 2 samples at each station is plotted

different in the 3 station-groups identified by TWINSPAN: $\mathrm{C} / \mathrm{N}=7.1$ to 7.9 at the offshore stations, 8.0 to 9.9 at the outer fjord stations, and 9.6 to 10.5 at the inner fjord stations (Fig. 2).

Many of the environmental variables (Table 1) are corlclated. All the isolation measures (sill depth, delta depth, sum delta depth, and distance to pool), the grain-size measures, and the measures of food supply/quality (loss-on-ignition, \% C, \% N and $\mathrm{C} / \mathrm{N}$ ) are strongly correlated (Table 2). In addition the correlation is strong between distance to pool and $\mathrm{C} / \mathrm{N}$ in the sediment $(r=0.96)$, and sill depth and $\mathrm{C} / \mathrm{N}, \% \mathrm{C}$ and $\% \mathrm{~N}$ in the sediment $(\mathrm{r}=-0.88, \mathrm{r}=-0.85$, and $\mathrm{r}=-0.79$, respectively). Delta depth and $\mathrm{C} / \mathrm{N}$ are also strongly correlated $(r=0.80)$. These correlations complicate attempts to unravel the causal factors involved in the faunal diversity and distribution patterns observed.

\section{General faunal pattern}

About 16000 specimens of molluscs were collected and identified to 65 species (Appendix 1). At all stations except Stn 4, the bivalves were numerically dominant, contributing from 79.2 to $99.1 \%$ to the numbers sampled (Table 3 ). Bivalves were less dominant at Stn 4 , with 45.7 to $54.8 \%$ of the individuals, while scaphopods and prosobranch gastropods contributed 24.0 to $33.5 \%$ and 11.3 to $15.8 \%$, respectively, to the number sampled. At Stn 10 the caudofoveates were relatively more abundant than at the other stations, contributing 9.1 to $10.8 \%$ to the number sampled. Table 4 shows the species contributing more than $1 \%$ to the number sampled in the 3 station-groups identified by TWINSPAN. The numeri-

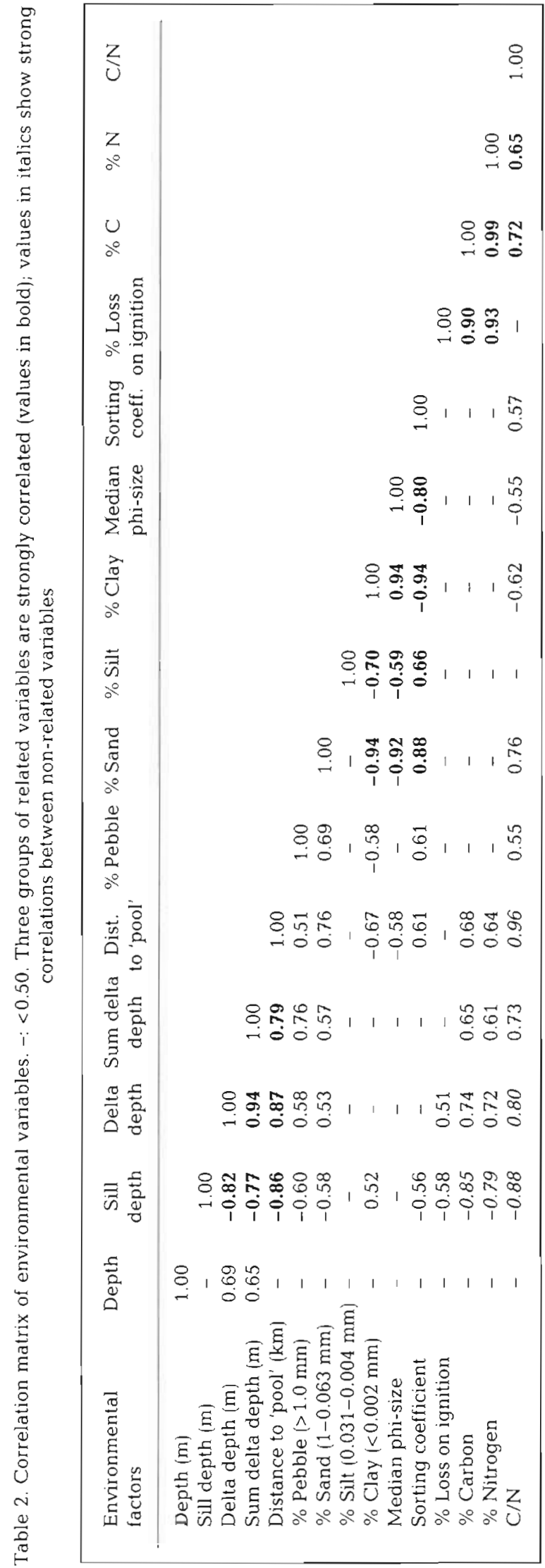




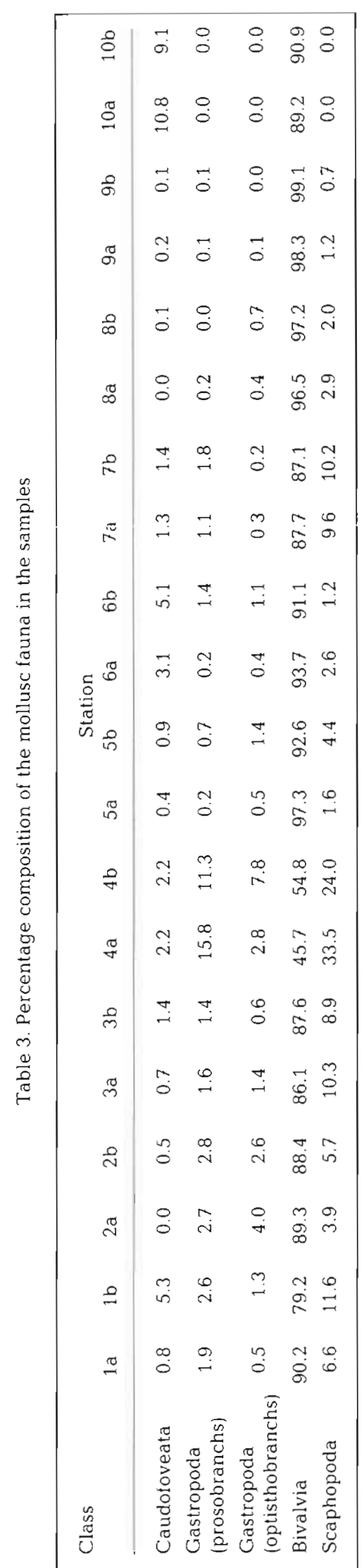

cally dominant species were fewer and more abundant in the inner parts of the fjords than offshore; the 3 most common species contributed $50 \%$ to the offshore fauna, $50 \%$ to the outer fjord fauna and $84 \%$ to the inner fjord fauna. Kelliella miliaris was the dominant species in the fjords while Thyasira ferruginea was dominant offshore and gradually decreased in abundance inward in the fjords. The second most dominant of fshore species, $T$. eumyaria, was not found at the inner fjord stations (Stns 8 to 10).

\section{Diversity}

When measured by numbers of species per sample, expected numbers of species per 200 individuals (E[S]), and the $H^{\prime}$ diversity index, diversity decreased markedly from the offshore stations (Stns 1 to 3 ) to the inner fjord stations (Stns 8 to 10) (Fig. 3). The Spearman rank correlation between diversity $\left(H^{\prime}\right)$ and environmental variables was high for sill depth $(\mathrm{r}=0.92)$, $\mathrm{C} / \mathrm{N}(\mathrm{r}=-0.86), \% \mathrm{C}(\mathrm{r}=-0.82)$ and distance to pool $(r=-0.81)$ (Table 5). These variables are all intercorrelated (Table 2).

\section{Faunal groups}

This presentation is confined to the 46 species used in the TWINSPAN classification. TWINSPAN first divided the samples into 2 groups (Table 6), samples from the offshore stations (Stns 1 to 3), and samples from the fjord stations (Stns $4 \& 6$ to 10). The replicates from fjord Stn 5 were split between the 2 groups. The fjord samples were further divided into 2 groups, samples from the outer fjord stations (Stns 4 to 7) and samples from the inner fjord stations (Stns 8 to 10 ).

The 4 main species groups identified by TWINSPAN, which we have named $A$ to $D$, were related to the sample groups as follows:

Species group A consists of 16 species having their main occurrence at the offshore stations but also with some records in the fjords. Astarte sulcata, Similipecten similis, Cerithiella metula and Limopsis minuta were only recorded offshore, however.

Species group B consists of 8 species common both at the offshore and outer fjord stations and occasionally recorded from inner fjord areas. Except for Thyasira ferruginea these species almost never occurred at inner fjord stations.

Species group $C$ consists of 11 species that were most frequent at the outer fjord stations but which were also common at the offshore and inner fjord stations. Except for Cadulus jeffreysii and Pseudomalletia obtusa, these species were widely distributed and occurred in all 3 areas. 
Table 4. Species contributing more than $1 \%$ to the mollusc fauna of the station-groups identified by the TWINSPAN analysis

\begin{tabular}{|c|c|c|c|c|c|}
\hline Stns 1 to 3 & & Stns 4 to 7 & & Stns 8 to 10 & \\
\hline Thyasira ferruginea & 20.9 & Kelliella miliaris & 27.4 & Kelliella miliaris & 51.8 \\
\hline T. eumyaria & 16.7 & Thyasira ferruginea & 12.8 & Thyasira equalis & 26.3 \\
\hline Yoldiella lucida & 12.2 & Entalina quinquangularis & 9.1 & Nucula tumidula & 6.0 \\
\hline Kelliella milianis & 5.3 & T. equalis & 8.7 & Yoldiella lucida & 2.2 \\
\hline Y. nana & 4.7 & Nucula tumidula & 7.9 & T. pygmaea & 1.7 \\
\hline Bathyarca pectunculoides & 42 & T. obsoleta & 6.0 & T. sarsii & 1.4 \\
\hline Cadulus jeffreysii/propinquus & 3.7 & T. pygmaea & 4.0 & Entalina quinquangularis & 1.1 \\
\hline Cerastoderma minimum & 3.2 & Yoldiella lucida & 3.8 & Y. nana & 1.1 \\
\hline Limopsis minuta & 3.1 & Alvania subsoluta & 3.4 & & \\
\hline Cuspidaria lamellosa & 2.5 & T. eumyaria & 3.4 & & \\
\hline T. obsoleta & 2.5 & Pseudomalletia obtusa & 1.9 & & \\
\hline Entalina quinquangularis & 2.4 & Y. nana & 1.8 & & \\
\hline T. granulosa & 2.3 & Cadulus jeffreysii/propinguus & 1.5 & & \\
\hline Dacrydium ockelmanni & 1.8 & & & & \\
\hline Abra nitida & 1.5 & & & & \\
\hline Nucula tumidula & 1.5 & & & & \\
\hline A. longicallus & 1.4 & & & & \\
\hline Sum \% & 89.9 & Sum \% & 91.8 & Sum \% & 91.6 \\
\hline
\end{tabular}

Species group D consists of 11 species with their highest abundance at the inner and outer fjord stations, and which were less frequently recorded offshore. Cuspidaria rostrata, Tropidomya cf. abbreviata, Lunatia montagui and Skenea basistriata were the only species not recorded at any of the offshore stations.

\section{Faunal pattern and environment}

The eigenvalues for CCA Axis 1 (0.31) and Axis 2 (0.12) were similar to those for the corresponding DCA axes (Axis $1=0.32$, Axis $2=0.07$ ), and the species-environmental correlations for the CCA axes were high (Table 7 ). Therefore the measured environ-

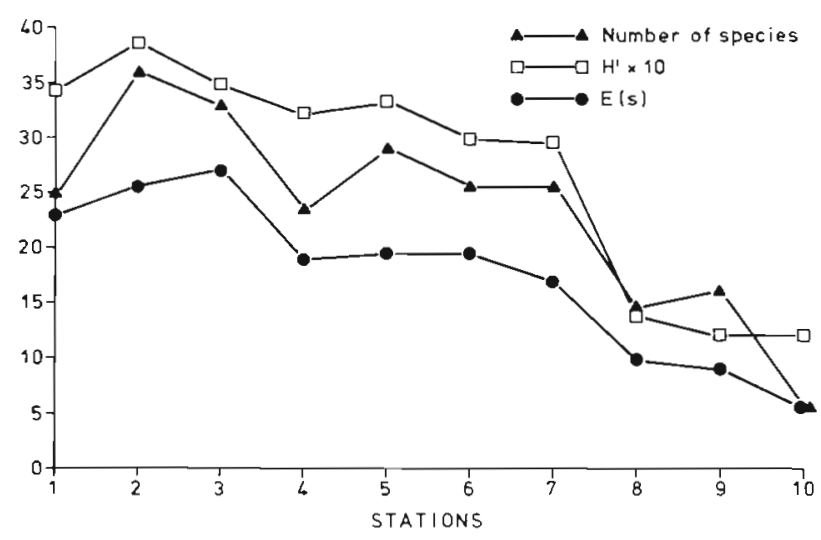

Fig. 3. Number of species, diversity $\left(H^{\prime}\right)$ and expected number of species $\mathrm{E}[\mathrm{S}]$ in samples rarefied to 200 individuals. Values are means for 2 replicates from each station mental variables appear to account for most of the variance in the species data. The constrained eigenvalue with all environmental variables was 0.76 (CCA), and the sum of unconstrained eigenvalues was 0.89 (DCA). Thus the 15 measured environmental variables account for $85 \%$ of the variance in the species data. With forward selection CCA identified 6 environmental variables that explained significant proportions ( $p<0.05$ in the unrestricted Monte Carlo permutation test) of the species variance (Table 8): sill depth, distance to 'species-pool', $\mathrm{C} / \mathrm{N}$ in sediment, loss on ignition, median phi-size, and \% $\mathrm{C}$ in sediment. These 6 variables accounted for $74 \%$ of the total variance in the species data. Sill depth repre-

Table 5. Spearman rank correlation (r) between diversity $\left(H^{\prime}\right)$ and environmental variables

\begin{tabular}{|lr|}
\hline Environmental factors & $H^{\prime}$ \\
\hline Sill depth $(\mathrm{m})$ & 0.92 \\
C/N & -0.86 \\
\% Carbon & -0.82 \\
Distance to pool $(\mathrm{km})$ & -0.81 \\
Delta depth $(\mathrm{m})$ & -0.78 \\
\% Nitrogen & -0.77 \\
Sum delta depth $(\mathrm{m})$ & -0.74 \\
\% Loss on ignition & -0.66 \\
\% Pebble $(>1.0 \mathrm{~mm})$ & -0.51 \\
\% Sand (1-0.063 mm) & -0.43 \\
Sorting coefficient & -0.42 \\
\% Clay (<0.002 mm) & 0.32 \\
Median phi-size & 0.22 \\
Depth (m) & -0.07 \\
\% Silt $(0.031-0.004 \mathrm{~mm})$ & 0.02 \\
\hline
\end{tabular}


Table 6. Sample groups (offshore, outer fjord and inner fjord) and species groups (A to D) identified by TWINSPAN (Hill 1979). Larval development is indicated by: L: lecithotrophic; P: planktotrophic $\mathrm{D}_{\text {: direct; }}$ ?: not known. Numbers in the table denote levels of abundance (no. of ind.) used in the calculations, as follows: 1 (1 to 4 ind.), 2 (5 to 9 ind.), 3 (10 to 49 ind.), 4 (50 to 99 ind.), 5 (100 to 499 ind.), 6 (500 to 999 ind.) and 7 (>1000 ind.). (-) indicates that no individuals were caught

\begin{tabular}{|c|c|c|c|c|c|}
\hline \multirow{2}{*}{$\begin{array}{c}\text { Larval } \\
\text { development }\end{array}$} & \multirow[t]{2}{*}{ Species } & \multicolumn{2}{|l|}{ Offshore } & \multirow{2}{*}{$\begin{array}{l}\text { Outer fjord } \\
7756644\end{array}$} & \multirow{2}{*}{$\begin{array}{l}\text { Inner fjord } \\
88991010\end{array}$} \\
\hline & & 113322 & 5 & & \\
\hline \multicolumn{6}{|c|}{ Species group A } \\
\hline $\mathrm{L}$ & Astarte sulcata & $--221-$ & - & ------ & ----- \\
\hline$?$ & Similipecten similis & ---111 & - & ------- & ----- \\
\hline$?$ & Limopsis minuta & 232133 & - & ------ & $--\cdots--$ \\
\hline$L$ & Dacrydium ockelmanni & 111233 & 1 & ------- & ------ \\
\hline $\mathrm{D}$ & Cerithiella metula & $1-1111$ & - & ------ & ----- \\
\hline$z$ & Anomia sp. & $1-111-$ & 1 & ------- & ----- \\
\hline$?$ & Chlamys sulcata & --2111 & 1 & ------ & ----- \\
\hline $\mathrm{L}$ & Pulsellum affine & $-111-1$ & - & $-----2-$ & ----- \\
\hline$?$ & Abra longicallus & 221212 & 1 & $1--111-$ & $---1--$ \\
\hline $\mathrm{P}$ & Cerastoderma minimum & 233323 & 2 & $-12-132$ & ----- \\
\hline $\mathrm{L}$ & Cuspidaria lamellosa & 333232 & 2 & $-2212--$ & $---1--$ \\
\hline $\mathrm{D}$ & Admete viridula & $111-11$ & 1 & $--11---$ & ----- \\
\hline $\mathrm{L}$ & Thyasira granulosa & 222233 & - & $23----$ & ----- \\
\hline $\mathrm{L}$ & Bathyarca pectunculoides & $232-43$ & 3 & $1-311-$ & $----1-$ \\
\hline$P$ & Philine scabra & ----11 & 1 & $----1--$ & ----- \\
\hline $\mathrm{L}$ & Setia turgida & $1-1-11$ & 1 & $11-\cdots$ & $-\cdots--$ \\
\hline \multicolumn{6}{|c|}{ Species group B } \\
\hline $\mathrm{P}$ & Abra nitida & 111133 & 2 & --21211 & ------ \\
\hline $\mathrm{L}$ & Cadulus subfusiforme & $3-\cdots$ & - & $-1---1-$ & ----- \\
\hline$?$ & Antalis agile & --1111 & - & $1-1--1-$ & ------ \\
\hline $\mathrm{L}$ & Thyasira eumyaria & 534444 & 3 & 4332321 & ----- \\
\hline $\mathrm{L}$ & T. ferruginea & 544455 & 5 & 5552232 & $1133--$ \\
\hline$?$ & Scaphander punctostriatus & $-1--32$ & 1 & ----123 & $-1----$ \\
\hline$?$ & Cylichna alba & -12111 & 2 & -1111111 & $-1----$ \\
\hline LD & Alvania subsoluta & $12-123$ & 1 & ----154 & ------ \\
\hline \multicolumn{6}{|c|}{ Species group C } \\
\hline $\mathrm{L}$ & Cadulus jeffreysii & $-333--$ & 1 & 3312132 & ----- \\
\hline $\mathrm{L}$ & Cuspidaria obesa & 111121 & 3 & 1121211 & $12-112$ \\
\hline $\mathrm{P}$ & Delectopecten vitreus & $1-111-$ & 1 & $---12--$ & $1--11-$ \\
\hline $\mathrm{L}$ & Yoldiella nana & 333323 & 3 & 1333322 & $1113-1$ \\
\hline $\mathrm{L}$ & Y. lucida & 334443 & 4 & 3333333 & $1235-2$ \\
\hline $\mathrm{D}$ & Melanella frielei & $--1---$ & - & $1-----$ & $---1--$ \\
\hline $\mathrm{L}$ & Entalina quinquangularis & $1-3233$ & 3 & 3332155 & $3333--$ \\
\hline $\mathrm{L}$ & Thyasira obsoleta & 313233 & 4 & 3453333 & $1123--$ \\
\hline $\mathrm{p}$ & Philine quadrata & $-11-11$ & 1 & ---123 & $111 \ldots$ \\
\hline$L$ & Caudofoveata indeterminate & $1312-1$ & 3 & 2213333 & -11112 \\
\hline$?$ & Pseudomalletia obtusa & --1111 & 3 & 1133333 & ----- \\
\hline \multicolumn{6}{|c|}{ Species group D } \\
\hline $\mathrm{L}$ & Antalis occidentale & $---1--$ & - & $1-1---1$ & ------ \\
\hline$P$ & Diaphana globosa & $1---11$ & - & $11-1-23$ & ----- \\
\hline $\mathrm{D}$ & Taranis moerchi & $---1-$ & 1 & $11--11-$ & $--11--$ \\
\hline $\mathrm{L}$ & Cuspidaria rostrata & ------ & 2 & $--111--$ & $-111--$ \\
\hline $\mathrm{P}$ & Kelliella miliaris & 232144 & 5 & 5555555 & $5667--$ \\
\hline $\mathrm{L}$ & Thyasira equalis & $1--11-$ & 4 & 3354433 & 443434 \\
\hline L & Nucula tumidula & 121123 & 5 & 3243354 & $3545-1$ \\
\hline $\mathrm{L}$ & Tropidomya cf. abbreviata & ----- & - & $----1-$ & $1111--$ \\
\hline $\mathrm{L}$ & Thyasira pygmaea & $--1---$ & 3 & 3323433 & $33331-$ \\
\hline $\mathrm{P}$ & Lunatia montagui & ------ & - & $11----$ & $---1--$ \\
\hline $\mathrm{L}$ & Skenea basistriata & ----- & - & $11--1--$ & ----- \\
\hline
\end{tabular}


Table 7 . Correlation matrix relating species axes to environmental variables ( $=$ interset correlations of environmental variables with axes) and fraction of variance in environmental data that is extracted by each axis

\begin{tabular}{|lrrrr|}
\hline $\begin{array}{l}\text { Environmental } \\
\text { variable }\end{array}$ & \multicolumn{5}{c}{ Axis } \\
\hline Sill depth (m) & 0.92 & 0.21 & 0.08 & -0.18 \\
Distance to 'pool' (km) & -0.91 & -0.18 & 0.17 & -0.26 \\
$\begin{array}{l}\text { Median phi } \\
\text { \% Loss on ignition }\end{array}$ & 0.31 & 0.42 & -0.04 & 0.70 \\
\% Carbon & -0.52 & -0.11 & 0.40 & 0.70 \\
C/N & -0.80 & -0.16 & 0.22 & 0.47 \\
& -0.87 & -0.41 & 0.10 & -0.16 \\
Fraction of variance & 0.57 & 0.08 & 0.04 & 0.22 \\
\hline
\end{tabular}

Table 8 . Variance potentially explained by each environmental variable before forward selection and variance explained with the addition of each environmental variable chosen by forward selection

\begin{tabular}{|lcc|}
\hline Variable & Before & Added \\
\hline Sill depth (m) & 0.28 & 0.28 \\
Distance to 'pool' (km) & 0.28 & 0.09 \\
Delta depth (m) & 0.27 & - \\
C/N & 0.26 & 0.10 \\
$\%$ Carbon & 0.23 & 0.05 \\
Sum delta depth (m) & 0.23 & - \\
\% Nitrogen & 0.21 & - \\
$\%$ Sand (1-0.063 mm) & 0.15 & - \\
$\%$ Loss on ignition & 0.14 & 0.08 \\
$\%$ Clay (<0.002 mm) & 0.12 & - \\
$\%$ Pebble (>1.0 mm) & 0.12 & - \\
Sorting coefficient & 0.11 & - \\
Depth (m) & 0.10 & - \\
Median phi & 0.10 & 0.06 \\
\% Silt (0.031-0.004 mm) & 0.04 & - \\
Sum of variance & 0.76 & 0.66 \\
\hline
\end{tabular}

sents $37 \%$ of the total variance explained by all the environmental variables.

CCA provides a combined ordination of species, sites and environmental variables (Fig. 4). The first and second CCA axes respectively explained 40 and $16 \%$ of the variance accounted for by all 15 environmental variables. The ordination shows that sill depth, distance to 'species-pool', $\mathrm{C} / \mathrm{N}$ ratio and \% $\mathrm{C}$ are all strongly correlated with Axis 1, with sill depth showing the best correlation ( $r=0.92)$ while \% loss on ignition and median phi are most strongly correlated with Axis 4. The correlations with Axes 2 and 3 are weak (Table 7). Fifty-seven percent of the variance in the environmental data is extracted by the first CCA axis. The gradient along Axis 1 represents localities from the Norwegian Trough (on the positive
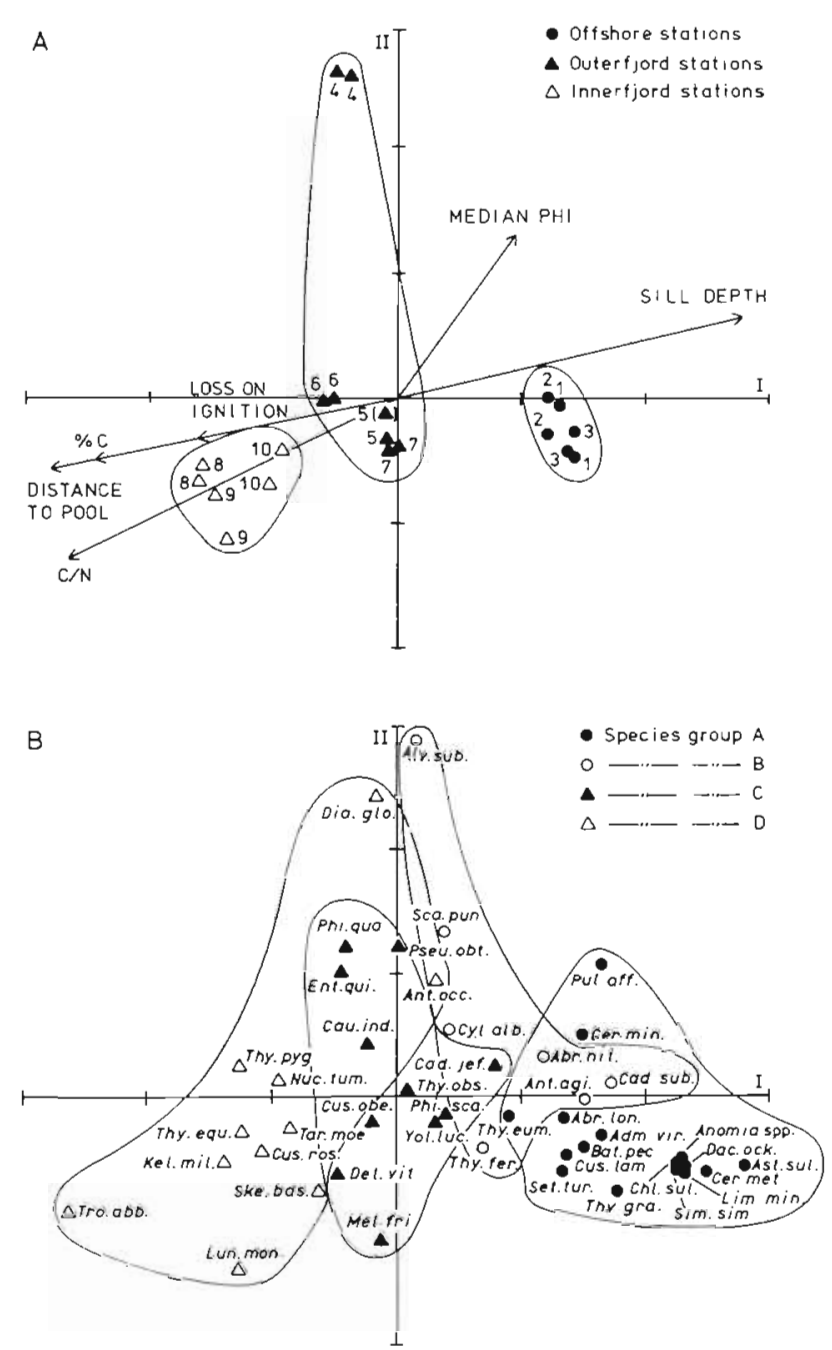

Fig. 4. Ordination plot of (A) stations and environmental variables and (B) mollusc species (see Table 6 for list). The encircled clusters and the symbols refer to sample- and species-groups identified by TWINSPAN

side of the axis) to the inner fjord (on the negative) (Fig. 4A). The results show that the offshore and inner fjord stations are rather well-defined groups while the outer fjord stations are more diffuse with the samples from Stn 4 as outliers. The species scores along Axis 1 show their association with the localities and the environmental gradients (Fig. 4B). Typical fjord species from localities with high $\% \mathrm{C}$ and $\mathrm{C} / \mathrm{N}$ are Tropidomya cf. abbreviata, Kelliella miliaris, Cuspidaria rostrata, Thyasira equalis, Thyasira pygmaea, Lunatia montagui, Nucula tumidula, and Taranis moerchi. Typical offshore species from localities with low \% C and C/N are Astarte sulcata, Cerithiella metula, Limopsis minuta, Dacrydium ockelmanni, Chlamys sulcata, Anomia sp., Similipecten similis and Thyasira granulosa. 


\section{DISCUSSION}

\section{Sampling}

The epibenthic sledge does not sample all benthic organisms equally well. For instance molluscs living deep in the sediment are not equally likely to be caught as those inhabiting the more superficial sediment layer. However, if the gear is carefully handled, the samples are comparable. It is reassuring that TWINSPAN, with 1 exception (Table 6), classifies all replicates as each other's closest neighbours. The exception, the 2 replicates from Stn 5, are placed on each side of the 2 replicates from $\operatorname{Stn} 7$. The second replicate $(5 b$, see Appendix 1 ) thus contained 8 more species and $32 \%$ more individuals than 5 a perhaps because the sledge dug deeper and thus filled up more quickly in the case of $5 \mathrm{a}$ than $5 \mathrm{~b}$. This hypothesis is strengthened when the species responsible for the difference in numbers are identified; the superficially living Kelliella miliaris accounts for most of the excess individuals of $5 \mathrm{~b}$, and, in addition to Yoldiella Iucida and Thyasira pygmaea, these species are all shallow burrowers. A number of heavier bivalves living deeper in the sediment are similarly found in higher numbers in $5 \mathrm{a}$ than in $5 \mathrm{~b}$. In the prior investigation in the same fjord system referred to below (Brattegard \& Høisæeter 1973), a similar sledge was used.

Because one of the faunal samples, Stn 2, was collected with the sediment samples, ca 5 mo later than the other sledge samples, there is a possibility that the composition of the fauna might have changed between the 2 sampling times. This station lies in the Norwegian Trough north of Stn 1 and northwest of Stn 3. The 3 localities cluster tightly together in the CCA-plot (Fig. 4), however, so there is no need to postulate a faunal variance component due to time of sampling. Furthermore, Josefson (1986) found no discernible temporal pattern over a $12 \mathrm{yr}$ period in the soft bottom benthos at 2 deep $(300 \mathrm{~m})$ stations in the eastern Skagerrak.

\section{The environment}

The sediment samples did not reveal any major differences in grain-size distribution between offshore and fjord localities. The occurrence of byssate mollusc species and sponges only offshore (discussed below), however, suggests that locally coarser sediment and higher currents may occur offshore than in fjords. Such local patches may not have been sampled for sediment since the box cores represent a very small area compared with the area sampled by the epibenthic sledge.
The range of monthly mean current velocities measured at $330 \mathrm{~m}$ depth in the Norwegian Trough (close to $\mathrm{Stn} 1$ ) is 0.9 to $5.5 \mathrm{~cm} \mathrm{~s}^{-1}$ (Furnes et al. 1986) while bottom current velocities generally are very low in fjord basins (Syvitski et al. 1987, p. 221). It has been shown for some fjords that the flat basin floor is remarkably uniform in its sediment grain-size distribution (Syvitski et al. 1987, p. 224).

A clear gradient in the amount and quality of organic matter in the sediment was observed. The increase in $\%$ loss on ignition and \% $\mathrm{C}$ together with an increased value of $\mathrm{C} / \mathrm{N}$ from offshore to the inner parts of the fjords suggests high input of terrigenous organic carbon which according to Burrell (1988) may be characteristic of boreal fjords.

\section{Faunal characteristícs}

Generally, the numerically dominating molluscan elements in the deep-water soft bottom macrobenthos are various groups of bivalves, sometimes together with small species of scaphopods. Gastropods, especially prosobranchs, are mostly represented by fairly scattered predatory species. In line with this general trend, the bivalves contributed more than $80 \%$ numerically to the fauna at all localities, except Stn 4 . At this station, the scaphopod Entalina quinquangularis, the prosobranch Alvania subsoluta, and 4 species of opisthobranchs together supplied roughly $50 \%$ of the individuals. A. subsoluta is the only prosobranch that is apt to occur in abundance on soft bottoms below $200 \mathrm{~m}$ in Norwegian waters, and its distribution seems to be confined to the outer parts of fjords (Brattegard \& Høisæeter 1973, Sneli 1979). In British waters, this species is found on muddy bottoms at depths of ca $200 \mathrm{~m}$ near the Isles of Scilly (Graham 1988). It is also known from the Mediterranean (Graham 1988). Stn 10 was the most topographically isolated locality, in a fjord with a very shallow sill $(20 \mathrm{~m})$, and this station had by far the highest organic content in the bottom sediment ( $30 \%$ weight loss on ignition, and $6.5 \%$ C). Of the few species present at Stn 10, Thyasira equalis dominated numerically, but the caudofoveates were also relatively abundant. Little is known about the ecology of this group, but they are presumed to feed selectively on organic particles in the sediment (Jones \& Baxter 1987 ), or to be predators (Josefson 1985, Gage \& Tyler 1991).

\section{Offshore fauna}

Of the 16 species having their main occurrence at offshore stations (Stns 1 to 3) (Table 6), Astarte sulcata, Similipecten similis, Limopsis minuta and Cerithiella metula only occurred offshore. Species that attach to a 
substrate (i.e. Anomia sp. and the byssates Limopsis minuta, Dacrydium ockelmanni and Bathyarca pectunculoides) belong to this fauna group which suggests that the offshore sediment was slightly different from the fjord sediment in grain-size composition.

\section{Offshore and outer fjord fauna}

Eight species seemed to flourish in the outer parts of the fjord and offshore, but occurred only in low numbers in the inner parts of the fjord system. Of these species, Abra nitida, Cadulus subfusiforme, Antalis agile, Thyasira eumyaria and Alvania subsoluta never occurred in the inner fjord samples. These species seem to avoid organically rich, high-sedimentation environments.

\section{Fjord fauna}

Eleven species belonged to the 'fjord' fauna. Of these Cuspidaria rostrata, Tropidomya cf. abbreviata, Lunatia montagui and Skenea basistriata were only found at the fjord stations. Few species seem to thrive in the organically rich inner parts of the fjords, but Thyasira equalis, Nucula tumidula and Tropidomya cf. abbreviata all had their highest numbers there. Thyasira sarsi, which was only found at Stn 10 , i.e. the most organic-rich and isolated fjord locality, also flourishes under rather extreme fjord-conditions. T. sarsi is known to occur at high densities in organic-polluted localities (Dando \& Southward 1986). Kelliella miliaris was found at all stations except Stn 10 and increased in numerical dominance from the outer to inner fjords. This species is exceedingly common in depths below ca $100 \mathrm{~m}$ in Norwegian fjords and the Skagerrak, and also (according to Warén 1989a) in the Mediterranean, but is apparently rare in the Norwegian Trough as well as in the wider context of the northeast Atlantic (cf. Odhner 1960, Bonnin et al. 1987).

\section{Correspondence between diversity and faunal pattern, and environmental variables}

The diversity of the mollusc fauna decreased steadily from the Norwegian Trough to the inner fjord, and the dominating species were fewer and more abundant in the fjords than outside. This pattern corresponds with what has been found for the amphipod fauna in fjords (Buhl-Jensen 1986, Buhl-Jensen \& Fosså 1991). The CCA results show that the species pattern is best explained by sill depth and, among the sediment variables, by $\mathrm{C} / \mathrm{N}$ (Table 8 ) while diversity was most strongly correlated with sill depth, $\mathrm{C} / \mathrm{N}, \% \mathrm{C}$ and distance to 'species pool' (Table 5). A high correlation between sill depth and diversity $\left(H^{\prime}\right)$ was also found for the amphipod fauna by Buhl-Jensen (1986), but the correlation between diversity $\left(H^{\prime}\right)$ and delta depth was higher $(-0.60$ vs -0.87$)$. The fact that sill depth best explains diversity and the faunal pattern suggests that sill depth is the determining factor for the environment inside fjords in general. In a hydrographic investigation of 28 west Norwegian fjords, Aure \& Stigebrandt (1989) showed that the oxygen consumption in fjord basins could be strongly correlated to sill depth and the mean depth of the basin inside the sill. They offered several explanations but preferred the following hypothesis: 'The vertical flux of organic matter is regionally horizontally homogeneous and decreases with depth'. Thus, the water masses above the sill are the same inside and outside a fjord and where the sill is deep, organic matter is flushed out. Consequently the shallower the sill the more organic matter that is trapped inside the fjord.

The connection between diversity and sill depth, $\mathrm{C} / \mathrm{N}, \% \mathrm{C}$ and distance to pool can be explained by at least 4 hypotheses that are discussed below:

First, the decrease in species diversity with distance from the 'species pool' may indicate that the colonization of the fjords is an ongoing process. The observed correlation between diversity and distance to pool agrees with the findings of Leal \& Bouchet (1991), who showed that the number of gastropod species on ocean seamounts decreased with distance from the shelf (their species pool). They hypothesized that the age of the seamounts could explain the diversity pattern: the youngest (ca 2.5 million yr B.P.) being farthest away from the coast.

In the deep (ca 280 to ca $1200 \mathrm{~m}$ ) basins below sill depth, the open Norwegian fjords are characterized by a distinct soft-bottom fauna consisting of mainly lusitanian-boreal species not found, or only occasionally found, in shallower waters. Most of the molluscs recorded in this investigation belong to this community and a typical example is Kelliella miliaris. Few of these species are common on the European shelf or in the North Sea (see e.g. the species lists of Hartley 1984 and Josefson 1985), but records from the upper slope of the Irish coast and the Atlantic coast of France and Spain may be found in the literature. However, many of the typical fjord bottom species or very closely related species reappear on the lower shelf or upper slope of the western Mediterranean (Carpine 1970). This suite of fjord bottom species 'suddenly' appeared in fjords in northern Norway around 7800 yr B.P. (Thomsen \& Vorren 1986), apparently replacing a group of more arctic species. This faunal change was associated with the influx of warm and saline Atlantic water masses to 
the northwestern Norwegian coast as the climate rapidly improved after the last glaciation. It is tempting to regard the present distribution of these species as a refugial one, with the Mediterranean and the Norwegian fjord basins as refugia for a faunal element of formerly more wide-spread distribution. Similar alternative fluctuations of faunal elements according to the prevailing warming or cooling trend are illustrated in Fig. 1 of Por (1978). Whether or not the deep fjord fauna today is in a stable or dynamic phase is unclear. There may be a slow influx of scattered lusitanianboreal species to our fjords, but this is difficult to substantiate without detailed analyses of fjord sediment cores. There is no indication that many species of molluscs have been added to the fjord bottom fauna since this period of rapid change 7000 to 8000 yr B.P., however. We thus find it unlikely that the decreased diversity inside fjords is a consequence of insufficient time for colonization to occur.

Second, the 'barrier hypothesis' states that the sill may act as a colonization barrier to benthic deep-living species. The shallower a sill is, the harder it may be for deep-water benthic animals and their larvae to pass, and thus diversity in the fjord basin will be lower (see e.g. Bouchet \& Taviani 1992). Furthermore, if the sill acts as a barrier against colonization, one would expect a higher proportion of species with good larval dispersal ability inside than outside the sill. Molluscs are known to have 3 main modes of larval development: species with planktotrophic larvae, that stay for relatively long periods in the upper water layers where they are actively feeding; species with nonfeeding, lecithotrophic larvae that are thought to have a substantially shorter pelagic stage; and species with direct development in which the pelagic stage is dispensed with altogether. Traditionally, it is presumed that species with planktotrophic larvae have better dispersal abilities than those with lecithotrophic larvae (Josefson 1985, Bouchet \& Taviani 1992), and a number of studies have been conducted to test the implication that more isolated habitats have a higher proportion of species with planktotrophic than lecithotrophic larvae (e.g. Josefson 1985, Leal \& Bouchet 1991). Several of these studies conclude, however, that the proportion of lecithotrophic larvae does not vary in a systematic manner with the degree of isolation, and thus the dispersal of the species does not depend on whether a lecithotrophic or planktotrophic larval stage is present (e.g. Leal \& Bouchet 1991). In addition, experiments have shown that the lecithotrophic eggs of some species have a high flotation rate, and thus have a far higher probability of being transported into the upper water masses than their presumed short development times should allow (Young \& Cameron 1987). Species with direct development, however, have consistently been shown to have less efficient dispersal abilities than those with pelagic stages (e.g. Leal \& Bouchet 1991). Comparing the distribution of the species with their larval development type (Table 6) reveals little difference in dispersal strategy between the mollusc fauna of the shelf and inner fjord stations. However, the lack of trend in distribution of species with direct development is based on too few species to completely rule out that fjord sills can act as barriers for some mollusc species.

In any case, we assume that molluscs as a group have much better dispersal abilities than amphipods which are brooders. Molluscs should be more widespread, and thus show a less clear diversity gradient than amphipods along the offshore-fjord transect. The observed low fjord diversity of both amphipods and molluscs indicates that the dispersal mechanisms are not the main reason for the pattern. We keep open the possibility, however, that low dispersal ability in combination with other factors is the explanation for the diversity gradient pattern of the 2 groups. Further investigations on the distributional pattern of amphipods along such a shelf-fjord gradient should clarify this question.

Third, offshore sediments may represent a more diverse habitat in food resources and in grain-size composition and thus be able to support more species. The $\mathrm{C} / \mathrm{N}$ ratio of offshore sediments $(7.1$ to 7.9$)$ indicate a richer and higher quality organic food source, which in turn might support more species, than fjord sediments ( 8.0 to 10.5 ). Low $\mathrm{C} / \mathrm{N}$ values ( 6 to 8 ) indicate a planktonic origin of the organic matter and thus presumably a varied and high quality food. High $\mathrm{C} / \mathrm{N}$ $(>10)$ values indicate organic matter of terrestrial origin or derived from benthic macrophytes, which is harder to decompose than microphyto detritus and animal remains (Walsh 1980, Faganeli et al. 1988).

The grain-size composition of offshore sediments may be more diverse, having a larger range in grainsize at sites, and being more patchily distributed than in fjords. This might provide habitats for more species, as mixed sediments are known to have a higher diversity of both infauna and epifauna (Gray 1974). The difference in grain-size heterogeneity is not evident from the sediment samples, which show little difference in sorting coefficients (standard deviation in grain-size) along the transect and no evidence of larger differences between subsamples and sites offshore than in fjords. However the distribution of the attached species Limopsis minuta, Dacrydium ockelmanni and Bathyarca pectunculoides mentioned above indicates the presence of at least scattered patches of coarse sediment particles offshore. The samples from offshore stations also contained sponges and sponge spicules, which were not found in the fjord samples. Sponges 
are known to have a special associated fauna and represent biologically induced environmental heterogeneity (Jumars \& Fauchald 1977). Together, this indicates that the offshore sediments are more diverse than the sediments of the fjord basins.

Fourth, high \% C in the sediment may represent high sedimentation rates and a large amount of food which may favour a few opportunistic species to the exclusion of others. Several studies have shown a negative correlation between the amount of organic matter in biotic sediments and diversity (e.g. Pearson \& Rosenberg 1978; Valiela 1984, p. 357; Weston 1990). In fjord basins with high levels of organic matter, the redox front may be within millimetres of the sediment water interface (Revsbech et al. 1980). Such an environment restricts the niches available to the obligate aerobic macro- and meio-infauna (Syvitski et al. 1987. p. 223).

Thus we find that our results correspond best with the third and fourth hypotheses. The connection between diversity, sill depth and distance to pool presumably represents a correlation between diversity and the environmental variables governed by sill depth and distance to pool. The effect of sill depth on water exchange and sedimentation rate in fjords has been demonstrated clearly by Aure \& Stigebrandt (1989), and distance to pool indicates how far inshore a locality is situated and thus the amount of terrestrial organic carbon that is imported. As briefly stated above, however, we still keep open the possibility that the fjord sills may act as a dispersal barrier for some organisms.

Acknowledgements. We thank P. G. Moore and H. J. B. Birks for reading an early version of the manuscript, and Elin Holm for drawing the illustrations. Pia Kupka Hansen and Karin Pittman were very helpful in arranging for the $\mathrm{C} / \mathrm{N}$ analyses, and the Inger R. Haldorsen's Fund financed the sediment analyses

Appendix 1. Abundance and number of mollusc species in the 22 samples used. - Species used in the multivariate analyses

\begin{tabular}{|c|c|c|c|c|c|c|c|c|c|c|c|c|c|c|c|c|c|c|c|c|c|c|}
\hline \multirow[t]{2}{*}{ Species } & \multicolumn{22}{|c|}{ Station } \\
\hline & $1 \mathrm{a}$ & $1 \mathrm{~b}$ & $2 a$ & $2 b$ & $3 a$ & $3 b$ & $4 a$ & $4 \mathrm{~b}$ & $5 a$ & $5 b$ & $6 a$ & & $6 \mathrm{~b}$ & $7 a$ & $7 \mathrm{~b}$ & $8 a$ & $8 \mathrm{~b}$ & $9 a$ & $9 b$ & $10 \mathrm{a}$ & $10 \mathrm{~b}$ & Sum \\
\hline - Caudofoveata & 3 & 16 & - & 3 & 2 & 5 & 24 & 13 & 3 & 10 & 14 & & 29 & 8 & 6 & - & 1 & 2 & 3 & 4 & 7 & 153 \\
\hline Solenogastres & - & - & - & - & 1 & - & - & - & - & - & - & & - & - & 5 & - & - & - & - & - & - & 6 \\
\hline $\begin{array}{l}\text { Polyplacophora } \\
\text { Indet. }\end{array}$ & - & - & - & - & - & - & - & - & - & - & - & & - & - & 1 & - & - & - & - & - & - & 1 \\
\hline $\begin{array}{l}\text { Gastropoda (prosobranch } \\
\text { Skeneidae }\end{array}$ & & & & & & & & & & & & & & & & & & & & & & \\
\hline $\begin{array}{l}\text { Skenea basistriata } \\
\text { Rissoidae }\end{array}$ & - & - & - & - & - & - & - & - & - & - & . & & 1 & 1 & 2 & - & - & - & - & - & - & 4 \\
\hline - Alvania subsoluta & 3 & 5 & 8 & 10 & - & 1 & 168 & 67 & - & 1 & - & & 1 & - & - & - & - & - & - & - & - & 264 \\
\hline $\begin{array}{l}\text { - Setia turgida } \\
\text { Naticidae }\end{array}$ & 1 & - & 1 & 1 & 2 & - & - & - & - & 3 & - & & - & 1 & 1 & - & - & - & - & - & - & 10 \\
\hline - Lunatia montagui & - & - & - & - & - & - & - & - & - & - & 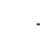 & & - & 1 & 1 & - & - & - & 1 & - & - & 3 \\
\hline Natica clausa & - & - & - & - & - & 1 & - & - & - & - & . & & - & - & - & - & - & - & - & - & - & 1 \\
\hline Cerithiellidae & & & & & & & & & & & & & & & & & & & & & & \\
\hline $\begin{array}{l}\text { - Cerithiella metula } \\
\text { Eulimidae }\end{array}$ & 2 & - & 2 & 3 & 1 & 2 & - & - & - & - & 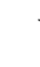 & & - & - & - & - & - & - & - & - & - & 10 \\
\hline Haliella stenostoma & - & - & - & - & - & - & - & - & - & - & - & & - & - & 3 & 1 & - & - & - & - & - & 4 \\
\hline $\begin{array}{l}\text { Melanella frielei } \\
\text { Curveulima }\end{array}$ & - & - & - & - & 1 & - & - & - & - & - & 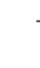 & & - & 1 & - & - & - & - & 1 & - & - & 3 \\
\hline macrophthalmica & - & 1 & - & - & - & - & - & - & - & - & 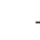 & & - & - & - & - & - & - & - & - & - & 1 \\
\hline Vitreolina philippii & - & - & - & - & - & - & - & - & - & - & - & & 5 & - & - & - & - & - & - & - & - & 5 \\
\hline Muricidae & & & & & & & & & & & & & & & & & & & & & & \\
\hline Trophonopsis barvicensis & $s-$ & - & 6 & - & - & - & - & - & - & - & & & - & 1 & - & - & - & - & - & - & - & 7 \\
\hline T. clathratus & - & - & - & - & - & - & - & - & - & 1 & & & - & - & - & - & - & - & - & - & - & 1 \\
\hline Cancellariidae & & & & & & & & & & & & & & & & & & & & & & \\
\hline $\begin{array}{l}\text { Admete viridula } \\
\text { Turridae }\end{array}$ & 1 & 2 & 1 & 2 & 1 & - & - & - & 1 & 1 & & & - & - & - & - & - & - & - & - & - & 10 \\
\hline Oenopota decussata & - & - & - & - & 2 & 1 & - & - & - & - & & & - & - & - & - & - & - & - & - & - & 3 \\
\hline Taranis borealis & - & - & - & - & - & - & - & - & 1 & - & & & - & - & - & - & - & - & 1 & - & - & 2 \\
\hline - T. moerchi & - & - & 1 & - & - & - & 1 & - & - & 2 & & & 1 & 2 & 1 & - & - & 1 & 3 & - & - & 12 \\
\hline
\end{tabular}


Appendix (continued)

\begin{tabular}{|c|c|c|c|c|c|c|c|c|c|c|c|c|c|c|c|c|c|c|c|c|c|}
\hline \multirow[t]{2}{*}{ Species } & \multirow[b]{2}{*}{$1 \mathrm{a}$} & \multirow[b]{2}{*}{$1 b$} & \multirow[b]{2}{*}{$2 \mathrm{a}$} & \multirow[b]{2}{*}{$2 b$} & \multirow[b]{2}{*}{$3 a$} & \multirow[b]{2}{*}{$3 b$} & \multirow[b]{2}{*}{$4 \mathrm{a}$} & \multirow[b]{2}{*}{$4 b$} & \multicolumn{3}{|c|}{ Station } & \multirow[b]{2}{*}{$6 b$} & \multirow[b]{2}{*}{$7 a$} & \multirow[b]{2}{*}{$7 \mathrm{~b}$} & & & & & & & \\
\hline & & & & & & & & & $5 a$ & $5 b$ & $6 a$ & & & & $8 \mathrm{a}$ & $8 b$ & $9 a$ & $9 b$ & $10 \mathrm{a}$ & $10 b$ & Sum \\
\hline Gastropoda (opisthobran & ichs) & & & & & & & & & & & & & & & & & & & & \\
\hline Pyramidellidae & & & & & & & & & & & & & & & & & & & & & \\
\hline Eulimella cf. compactilis & - & - & 2 & - & - & - & - & - & - & 2 & - & - & - & - & - & - & - & - & - & - & 4 \\
\hline Menestho divisa & - & - & - & - & - & - & - & - & - & - & - & 1 & - & - & - & - & - & - & - & - & 1 \\
\hline Menesthosp. & - & - & - & - & - & - & - & - & - & 1 & - & - & - & - & - & - & - & - & - & - & 1 \\
\hline Diaphanidae & & & & & & & & & & & & & & & & & & & & & \\
\hline - Diaphana globosa & 1 & - & 1 & 1 & - & - & 9 & 19 & - & - & 1 & - & 1 & 1 & - & - & - & - & - & - & 34 \\
\hline Diaphana sp. & - & - & - & - & - & - & - & - & - & 1 & - & - & - & - & - & - & - & - & - & - & 1 \\
\hline Philinidae & & & & & & & & & & & & & & & & & & & & & \\
\hline Philine finmarchica & - & - & - & 2 & - & - & - & - & - & - & - & - & - & - & - & - & - & - & - & - & 2 \\
\hline - P. quadrata & - & 1 & 3 & 1 & 1 & - & 9 & 11 & - & 2 & - & 1 & - & - & 2 & 3 & 1 & - & - & - & 35 \\
\hline - P. scabra & - & - & 3 & 1 & - & - & - & - & - & 1 & - & 2 & - & - & - & - & - & - & - & - & 7 \\
\hline $\begin{array}{l}\text { Philine sp. } \\
\text { Scaphandridae }\end{array}$ & - & - & - & - & - & - & - & - & 1 & - & - & - & - & - & - & - & - & - & - & - & 1 \\
\hline - Cylichna alba & - & 1 & 2 & 1 & 5 & 2 & 3 & 4 & 3 & 7 & 1 & 2 & - & 1 & - & 4 & - & - & - & - & 36 \\
\hline Scaphander Lignarius & - & - & 1 & - & - & - & - & - & - & - & - & - & - & - & - & - & - & - & - & - & 1 \\
\hline - S. punctostriatus & - & 2 & 16 & 9 & - & - & 9 & 13 & - & 2 & - & 1 & - & - & - & 2 & - & - & - & - & 54 \\
\hline Scaphander sp. & 1 & - & - & - & - & - & - & - & - & - & - & - & - & - & - & - & - & - & - & - & 1 \\
\hline $\begin{array}{l}\text { Bivalvia } \\
\text { Nuculidae }\end{array}$ & & & & & & & & & & & & & & & & & & & & & \\
\hline $\begin{array}{l}\text { Nucula tumidula } \\
\text { Nuculanidae }\end{array}$ & 4 & 6 & 8 & 18 & 4 & 3 & 117 & 83 & 80 & 102 & 49 & 34 & 19 & 5 & 34 & 102 & 99 & 247 & - & 3 & 1017 \\
\hline $\begin{array}{l}\text { Nuculanidae } \\
\text { - Yoldiella lucida }\end{array}$ & 10 & 18 & 89 & 45 & 98 & & & 18 & 46 & 74 & 24 & & 16 & 10 & 1 & 5 & רת & 122 & & 5 & 730 \\
\hline - Y.nana & 14 & $\begin{array}{l}10 \\
25\end{array}$ & 69 & $\begin{array}{l}40 \\
15\end{array}$ & $\begin{array}{l}98 \\
21\end{array}$ & 27 & $\begin{array}{r}10 \\
5\end{array}$ & 9 & $\begin{array}{l}40 \\
23\end{array}$ & $\begin{array}{l}74 \\
19\end{array}$ & $\begin{array}{l}24 \\
15\end{array}$ & $\begin{array}{l}30 \\
14\end{array}$ & $\begin{array}{r}10 \\
4\end{array}$ & $\begin{array}{l}10 \\
12\end{array}$ & $\begin{array}{l}1 \\
3\end{array}$ & $\begin{array}{l}3 \\
2\end{array}$ & $\begin{array}{r}2 f \\
1\end{array}$ & $\begin{array}{r}132 \\
23\end{array}$ & - & $\begin{array}{l}3 \\
4\end{array}$ & 242 \\
\hline Yoldiella indet. & - & - & - & - & - & 1 & - & - & - & - & - & - & - & - & - & - & - & - & - & - & 1 \\
\hline Malletiidae & & & & & & & & & & & & & & & & & & & & & \\
\hline $\begin{array}{l}\text { Pseudomalletia obtusa } \\
\text { Mytilidae }\end{array}$ & - & - & 1 & 2 & 3 & 1 & 22 & 14 & 12 & 27 & 18 & 12 & 3 & 2 & - & - & - & - & - & - & 117 \\
\hline Indet. & - & - & - & - & 1 & - & 1 & 4 & - & - & - & - & - & - & - & - & - & - & - & - & 6 \\
\hline $\begin{array}{l}\text { Dacrydium ockelmanni } \\
\text { Limidae }\end{array}$ & 3 & 4 & 15 & 21 & 3 & 8 & - & - & - & 1 & - & - & - & - & - & - & - & - & - & - & 55 \\
\hline - Bathyarca pectunculoides & 59 & 16 & 51 & 47 & 8 & - & - & - & 14 & 29 & 1 & 1 & 1 & - & - & - & - & - & 1 & - & 178 \\
\hline $\begin{array}{l}\text { Limatula gwyni } \\
\text { Limopsidae }\end{array}$ & - & - & 1 & - & - & - & - & - & - & - & - & - & - & - & - & - & - & - & - & - & 1 \\
\hline $\begin{array}{l}\text { Limopsis minuta } \\
\text { Pectinidae }\end{array}$ & 7 & 14 & 34 & 29 & 5 & 3 & - & - & - & - & - & - & - & - & - & - & - & - & - & - & 92 \\
\hline - Chlamys sulcata & - & - & 4 & 2 & 9 & 2 & - & - & - & 1 & - & - & - & - & - & - & - & - & - & - & 18 \\
\hline Cyclopecten imbrifer & - & - & - & - & - & 2 & - & - & 1 & - & - & - & - & - & - & - & - & - & - & - & 3 \\
\hline - Delectopecten vitreus & 1 & - & 1 & - & 1 & 1 & - & - & - & 2 & 2 & 5 & - & - & 3 & - & - & 3 & 3 & - & 22 \\
\hline $\begin{array}{l}\text { Similipecten similis } \\
\text { Anomiidae }\end{array}$ & - & - & 4 & 1 & - & 1 & - & - & - & - & - & - & - & - & - & - & - & - & - & - & 6 \\
\hline $\begin{array}{c}\text { Anomia sp. } \\
\text { Thyasiridae }\end{array}$ & 1 & - & 1 & - & 2 & 1 & - & - & - & 1 & - & - & - & - & - & - & - & - & - & - & 6 \\
\hline - Thyasira obsoleta & 11 & 2 & 19 & 18 & 17 & 6 & 27 & 14 & 118 & 88 & 15 & 18 & 39 & 70 & 1 & 1 & 8 & 29 & - & - & 501 \\
\hline T. sarsii & - & - & - & - & - & - & - & - & - & - & - & - & - & - & - & - & - & - & 3 & - & 3 \\
\hline - T. equalis & 2 & _ & 1 & - & - & 2 & 22 & 26 & 125 & 95 & 60 & 92 & 38 & 40 & 66 & 53 & 43 & 92 & 24 & 53 & 835 \\
\hline - T. granulosa & 7 & 7 & 28 & 19 & 5 & 5 & - & - & - & - & - & - & 5 & 12 & - & - & - & - & - & - & 88 \\
\hline - T. eumyaria & 109 & 42 & 85 & 62 & 59 & 74 & 5 & 1 & 37 & 42 & 9 & 15 & 52 & 45 & - & - & - & - & - & - & 637 \\
\hline - T. ferruginea & 119 & 62 & 137 & 103 & 89 & 53 & 15 & 7 & 159 & 123 & 7 & 9 & 245 & 231 & 3 & 3 & 12 & 38 & - & _ & 1415 \\
\hline T. pygmaea & - & - & - & - & 1 & - & 29 & 27 & 8 & 17 & 28 & 62 & 12 & 29 & 18 & 21 & 11 & 38 & 1 & - & 302 \\
\hline Lasaeidae & & & & & & & & & & & & & & & & & & & & & \\
\hline Montacuta ferruginosa & - & - & - & - & - & - & - & - & - & - & - & 1 & - & - & - & - & - & - & - & - & 1 \\
\hline Mysella tumidula & 3 & - & - & - & - & - & - & - & 3 & - & - & - & - & - & - & - & - & - & - & - & 6 \\
\hline Astartidae & & & & & & & & & & & & & & & & & & & & & \\
\hline $\begin{array}{l}\text { Astarte sulcata } \\
\text { Cardiidae }\end{array}$ & - & - & 1 & - & 6 & 7 & - & - & - & - & - & - & - & - & - & - & - & - & - & - & 14 \\
\hline $\begin{array}{l}\text { Cerastoderma minimum } \\
\text { Scrobiculariidae }\end{array}$ & 9 & 12 & 5 & 13 & 25 & 15 & 14 & 5 & 5 & 5 & - & 2 & - & 1 & - & - & - & - & - & - & 111 \\
\hline - Abra longicallus & 9 & $\cdot 7$ & 3 & 5 & 3 & 5 & 2 & - & - & 1 & 2 & 1 & 1 & - & - & - & - & 2 & - & - & 41 \\
\hline A. nitida & 3 & 3 & 18 & 25 & 1 & 1 & 1 & 4 & 7 & 5 & 1 & 5 & - & - & - & - & - & - & - & - & 74 \\
\hline
\end{tabular}


Appendix (continued)

\begin{tabular}{|c|c|c|c|c|c|c|c|c|c|c|c|c|c|c|c|c|c|c|c|c|c|}
\hline \multirow[t]{2}{*}{ Species } & \multicolumn{21}{|c|}{ Station } \\
\hline & $1 \mathrm{a}$ & $1 b$ & $2 a$ & $2 b$ & $3 a$ & $3 b$ & $4 a$ & $4 \mathrm{~b}$ & $5 a$ & $5 b$ & $6 a$ & $6 b$ & $7 a$ & $7 \mathrm{~b}$ & $8 a$ & $8 \mathrm{~b}$ & $9 \mathrm{a}$ & $9 \mathrm{~b}$ & $10 \mathrm{a}$ & $10 \mathrm{~b}$ & Sum \\
\hline \multicolumn{22}{|l|}{ Scrobiculariidae (continued) } \\
\hline Abrasp. & - & - & - & - & - & - & - & - & - & - & - & -- & - & - & 2 & - & - & - & - & - & 2 \\
\hline Kelliellidae & & & & & & & & & & & & & & & & & & & & & \\
\hline $\begin{array}{l}\text { Kelliella miliaris } \\
\text { Hiatellidae }\end{array}$ & 6 & 10 & 83 & 78 & 5 & 1 & 210 & 117 & 172 & 382 & 2195 & 199 & 113 & 245 & 357 & 996 & \multicolumn{2}{|c|}{6214068} & - & $\sim$ & 7858 \\
\hline Hiatella arctica & - & - & - & 1 & - & - & - & - & - & - & - & - & - & - & - & - & - & - & - & - & 1 \\
\hline Verticordiidae & & & & & & & & & & & & & & & & & & & & & \\
\hline $\begin{array}{l}\text { Lyonsiella abyssicola } \\
\text { Cuspidariidae }\end{array}$ & - & - & - & - & 1 & 1 & - & - & - & - & - & - & - & - & - & - & - & - & - & - & 0 \\
\hline - Cuspidaria lamellosa & 11 & 11 & 18 & 7 & 11 & 7 & - & - & 8 & 6 & 1 & 5 & - & 5 & - & - & - & 3 & - & - & 93 \\
\hline C. obesa & 2 & 1 & 7 & 2 & 1 & 3 & 2 & 2 & 6 & 13 & 1 & 7 & 2 & 1 & 3 & 6 & - & 2 & 1 & 5 & 67 \\
\hline C. rostrata & - & - & - & - & - & - & - & - & 3 & 9 & 2 & 2 & - & - & - & 2 & 1 & 4 & - & - & 23 \\
\hline $\begin{array}{l}\text { Tropidomya cf. abbreviato } \\
\text { Dentaliidae }\end{array}$ & $2-$ & - & - & - & - & - & 1 & - & - & - & - & - & - & - & 2 & 4 & 3 & 3 & - & - & 13 \\
\hline - Antalis agile & - & - & 1 & 3 & 4 & 2 & 1 & - & 1 & - & - & - & 2 & - & - & - & - & - & - & - & 14 \\
\hline A. occidentale & - & - & - & - & - & 1 & - & 2 & 2 & - & - & - & 2 & - & - & - & - & - & - & - & 7 \\
\hline $\begin{array}{l}\text { Entalinidae } \\
\text { Entalina quinquangulari } \\
\text { Siphonodentaliidae }\end{array}$ & is 4 & - & 26 & 30 & 11 & 7 & 339 & 137 & 10 & 46 & 6 & 4 & 32 & 49 & 15 & 24 & 10 & 34 & - & - & 784 \\
\hline - Pulsellum affine & - & 1 & - & 1 & 4 & 3 & 6 & - & - & - & - & - & - & - & - & - & - & - & - & - & 15 \\
\hline P. lofotense & - & - & - & 1 & - & - & - & - & - & - & - & - & 1 & - & - & - & - & - & - & - & 2 \\
\hline Gadilidae & & & & & & & & & & & & & & & & & & & & & \\
\hline $\begin{array}{l}\text { - Cadulus jeffieysiil } \\
\text { propinquus }\end{array}$ & - & 34 & - & - & 26 & 18 & 12 & 6 & 1 & 3 & 6 & 3 & 23 & 33 & - & - & - & - & - & - & 165 \\
\hline C. subfusiforme & 21 & - & - & - & - & - & 1 & - & - & - & - & - & - & 1 & - & - & - & - & - & - & 23 \\
\hline Sum & 377 & 303 & 694 & 582 & 440 & 348 & 1071 & 603 & 851 & 1125 & 5459 & 564 & 627 & 813 & 511 & 1229 & 840 & 4727 & 37 & 77 & 16278 \\
\hline Sum species & 26 & 24 & 38 & 34 & 33 & 33 & 26 & 21 & 25 & 33 & $\begin{array}{ll}322 \\
2\end{array}$ & 29 & 27 & 24 & 14 & 15 & 13 & 19 & 6 & 5 & \\
\hline
\end{tabular}

\section{LITERATURE CITED}

Aksnes, D. L., Aure, J., Kaartvedt, S., Magnesen, T., Richard, J. (1989). Significance of advection for the carrying capacities of fjord populations. Mar. Ecol. Prog. Ser. 50: $263-274$

Aure, J., Stigebrandt, A. (1989). On the influence of topographic factors upon the oxygen consumption rate in sill basins of fjords. Estuar. coast. Shelf Sci. 28: 59-69

Bonnin, J., Rodriguez Babio, C., Rubio, F. (1987). Contribution à la connaissance de Kelliella miliaris (Philippi, 1844) Mollusque, Bivalve, Eulamellibranche des côtes d'Europe. Vie Milieu 37: 181-186

Bouchet, P., Taviani, M. (1992). The Mediterranean deep-sea fauna: pseudopopulations of Atlantic species? Deep Sea Res. 39: 169-184

Bouchet, P., Warén, A. (1986). Revision of the northeast Atlantic bathyal and abyssal Aclididae, Eulimidae, Epitoniidae (Mollusca, Gastropoda). Boll. Malacol., Milano, Suppl. 2: 299-576

Brattegard, T., Høisæter, T. (1973). Supplerende undersøkelser av Fensfjordens dype blotbunners dyreliv. Rapport til Norsk Hydro, Best. nr. T. 67402/NH/Mo, p. 1-71

Buchanan, J. B. (1984). Sediment analysis. In: Holme, N. A., McIntyre, A. D. (eds.) Methods for the study of marine benthos, IBP Handbook 16, 2nd edn. Blackwell, London, p. $41-65$

Buhl-Jensen, L. (1986). The benthic amphipod fauna of the west-Norwegian continental shelf compared with the fauna of five adjacent fjords. Sarsia 71: 193-208
Buhl-Jensen, L., Fosså, J. H. (1991). Hyperbenthic crustacean fauna of the Gullmarfjord area (western Sweden): species richness, seasonal variation and long-term changes. Mar. Biol. 109: 245-258

Burrell, D. C. (1988). Carbon flow in fjords. Oceanogr. mar. Biol. A. Rev. 26: 143-226

Carpine, C. (1970). Écologie de l'étage bathyal dans la Méditerranée occidentale. Mem. Inst. Ocean., Monaco 2: $1-146$

Dando, P. R., Southward, A. J. (1986) Chemoautotrophy in bivalve molluscs of the genus Thyasira. J. mar. biol. Ass. U.K. 66: $915-929$

Faganeli, J., Malej, A., Pezdic, J., Malacici, V. (1988). C : N : P ratios and stable $C$ isotopic ratios as indicators of sources of organic matter in the Gulf of Trieste (Northern Adriatic). Oceanologica Acta 11: 377-382

Furnes, G. K., Hackett, B., Sætre, R. (1986). Retroflection of Atlantic water in the Norwegian Trench. Deep Sea Res. 33: $247-265$

Gage, J. D., Tyler, P. A. (1991). Deep-sea biology: a natural history of organisms at the deep-sea floor Cambridge University Press, Cambridge

Golmen, L. G. (1991). Vassutskifting i Lurefjorden og Seimsfjorden. Resultat frå granskingar i 1989-1990. NIVA (Norwegian Institute of Water Research) - rapport $0-89123$, p. $1-78$

Graham, A. (1988). Molluscs: prosobranch and pyramidellid gastropods. Synop. Br. Fauna 2 (2nd edn.) 1--662

Gray, J S. (1974). Animal-sediment relationships. Oceanogr. mar. Biol. A. Rev. 12: 223-261 
Hartley, J. P. (1984). The benthic ecology of the Forties oilfield (North Sea). J. exp. mar. Biol. Ecol. 80: 161-195

Hill, M. O. (1979). TWINSPAN - a FORTRAN program for arranging multivariate data in an ordered two-way table by classification of individuals and attributes. Cornell University, Ithaca, NY

Høisæter, T. (1986). An annotated check-list of marine molluscs of the Norwegian coast and adjacent waters. Sarsia $71: 73-145$

Holthe, T (1978). The zoogeography of the Terebellomorpha (Polychaeta) of the northern European waters. Sarsia 63 $191-198$

Hurlbert, S. H. (1971). The nonconcept of species diversity: a critique and alternative parameters. Ecology 52 $577-586$

James, F. C., Rathbun, S. (1981). Rarefaction, relative abundance, and diversity of avian communities. Auk 98 $785-800$

Jonasson, A., Olausson, E. (1966). New devices for sediment sampling. Mar. Geol. 4: 365-372

Jones, A. M., Baxter, J. M. (1987). Molluscs: Caudofoveata Solenogastres Polyplacophora and Scaphopoda. Synop. Br. Fauna 37: 1-123

Josefson, A. B. (1985). Distribution of diversity and functional groups of marine infauna in the Skagerrak leastern North Sea) - can larval availability affect diversity? Sarsia $70: 229-249$

Josefson, A. B. (1986). Temporal heterogeneity in deep-water soft-sediment benthos - an attempt to reveal temporal structures. Estuar. coast. Shelf Sci. 23: 147-169

Jumars, P. A., Fauchald, K. (1977). Between-community contrast in successful polychaete feeding strategies. In: Coull, B. S. (ed.) Ecology of marine benthos. Univ. South Carolina Press, Columbia, p. 1-20

Leal, J. H., Bouchet, P. (1991). Distribution patterns and dispersal of prosobranch gastropods along a seamount chain in the Atlantic Ocean. J. mar. biol. Ass. U.K. 71: 11-25

Magurran, A. E. (1988). Ecological diversity and its measurement. Cambridge University Press, Cambridge

McIntyre, A. D. (1961). Quantitative differences in the fauna of boreal mud associations. J, mar. biol. Ass. U.K. 41: 599-616

McIntyre, A. D. (1964). Meiobenthos of sub-littoral muds. J. mar. biol. Ass. U.K. 44: 665-674

Mileikovsky, S. A. (1971). Types of larval development in marine bottom invertebrates, their distribution and ecological significance: a re-evaluation. Mar. Biol. 10 $193-213$

Ockelmann, K. W. (1965). Developmental types in marine bivalves and their distribution along the Atlantic coast of Europe. In: Cox, L. R., Peake, J. F. (eds.) Proc. First Europ Malac. Congr., London, p. 25-35

Odhner, N. H. (1960). Mollusca. Rep. Swed. Deep-Sea Exped. 2 (Zoology) 22: $367-400$

Pearson, T H. (1980). Macrobenthos of fjords. In: Freedland, H. J., Farmer, D. M., Levings, C. D. (eds.) Fjord oceanography. Plenum Publ. Corp., New York, p. 569-602
Pearson, T. H., Rosenberg, R. (1978). Macrobenthic succession in relation to organic enrichment and pollution of the marine environment. Oceanogr. mar. Biol. A. Rev. 16 $229-311$

Por, F. D. (1978). Lessepsian migration. Springer-Verlag, Berlin

Revsbech, N. P., Jørgensen, B. B., Blackburn, T. H. (1980). Oxygen in the sea bottom measured with a microelectrode. Science 207: 1355-1356

Shannon, C. E., Weaver, W. (1949). The mathematical theory of communication. Univ. Illinois Press, Urbana

Simberloff, D. (1978). Use of rarefaction and related methods in ecology. In: Dickson, K. L., Cairns, J., Livingston, R. J. (eds.) Biological data in water pollution assessment: quantitative and statistical analyses, ASTM STP 652. American Society for Testing and Materials, Philadelphia, p. $150-165$

Sneli, J. A. (1979). Prosobranchia from Sognefjorden, western Norway. Sarsia 64: 259-267

Soetaert, K., Heip, C. (1990). Sample-size dependence of diversity indices and the determination of sufficient sample size in a high-diversity deep-sea environment. Mar. Ecol. Prog. Ser. 59: 305-307

Syvitski, J. P. M., Burrell, D. C., Skei, J. M. (1987). Fjords: processes and products. Springer, New York

ter Braak, C. J. F. (1987). Ordination. In: Jongman, R. H. G., ter Braak, C. J. F., van Tongeren, O. F. R. (eds.) Data analysis in community and landscape ecology. Pudoc, Wageningen, p. 91-173

ter Braak, C. J. F. (1990). CANOCO - a FORTAN program for canonical community ordination by (partial) (detrended) (canonical) correspondence analysis and redundancy analysis (version 3.10). ITI-TNO, Wageningen

Thomsen, E., Vorren, T. O. (1986). Macrofaunal palaeoecology and stratigraphy in Late Quaternary shelf sediments of nothern Norway. Palaeogeogr. Palaeoclimat. Palaeoecol. 56: $103-150$

van Tongeren, O. F. R. (1987). Cluster analysis. In: Jongman, R. H. G., ter Braak, C. J. F., van Tongeren, O. F. R. (eds.) Data analysis in community and landscape ecology. Pudoc, Wageningen, p. 174-212

Valiela, I. (1984). Marine ecological processes. SpringerVerlag, New York

WaIsh, J. J. (1980). Shelf-sea ecosystems. In: Longhurst, A. R. (ed.) Analysis of marine ecosystems. Academic Press, New York, p. 159-196

Warén, A. (1989a). New and little known Mollusca from Iceland. Sarsia 74: 1-28

Warén, A. (1989b). Taxonomic comments on some protobranch bivalves from the northeastern Atlantic. Sarsia 74 : $223-259$

Weston, D. P. (1990). Quantitative examination of macrobenthic community changes along an organic enrichment gradient. Mar. Ecol. Prog. Ser. 61: 233-244

Young, C. M., Cameron, J. L. (1987). Laboratory and in situ flotation rates of lecithotrophic eggs from the bathyal echinoid Phormosoma placenta. Deep Sea Res. 34: 1629-1639

Manuscript first received: September 21, 1992

Revised version accepted: May 4, 1993 